\title{
Location of super and hypermarkets in the city of Ústí nad Labem
}

\author{
Petra Olšová ${ }^{*}$ - Michaela Jánská ${ }^{2}$ \\ ${ }^{1}$ Department of Regional Development and Public administration, \\ J. E. Purkyně University in Ústí nad Labem, Moskevská 54, 400 \\ 96 Ústí nad Labem, Czech Republic \\ * petra.olsova@ujep.cz \\ ${ }^{2}$ Department of Management, J. E. Purkyně University in Ústí \\ nad Labem, Moskevská 54, 40096 Ústí nad Labem, Czech
}

Abstract: Retail stores are a common part of our everyday life. We focus on the site selection of supermarkets and hypermarkets in Ústí nad Labem and analyze the role of selected factors that drive the site selection of these super/hypermarkets. The role of the factors is verified by a correlation analysis. In the city of Ústí nad Labem, retail units of the supermarket or hypermarket type are unevenly distributed and are concentrated in the more central areas of the city. The location of stores has no power association with monitored factors. The result is certainly strongly influenced by the lack in availability of relevant data.

Key words: retail, location factors, Reilly's model

Highlights for public administration, management and planning:

- location of retail centers does not display a significant correlation with the number

of inhabitants living in a location

- commuting distances of retail centers frequently overlap, forcing their competitiveness

- future effort must be aimed at database building for analyses of further location factors

Received: 12 Jan 2016 - Received in revised form: 28 Apr 2016 - Accepted: 5 May 2016

\section{Introduction}

Retail stores are a common part of our everyday lives; most purchases have moved to supermarkets or hypermarkets. After the period of greatest expansion, we have now encountered a situation where some of these stores are closing down. The overall economic development, as well as the specific location of the shops, and the resulting strength of their competition also certainly play a role in this. Some shops, therefore, fight for the same groups of customers within a given area. This paper focuses on the site selection of supermarkets and hypermarkets in Ústí nad Labem, on their specific location and catchment areas. The decision where to locate a retail store is one of the most important strategic decisions that distributors have to make, as this affects the ability of the store to attract customers. The site selection relates to the business philosophy of a specific retail store, to the type of purchasing conditions in the area and to the actual location of the store.

The aim of this paper is to define the specific location of supermarkets and hypermarkets in Ústí nad Labem, and then to analyze the role of selected factors that drove the site selection of these business units. However, the site selection factors are significantly reduced by the lack of available data. Their connection to a specific store location is assessed using correlation analysis. For a graphical representation of store locations and related characteristics ArcGIS has been used.

\section{Site location factors}

There are a whole range of factors that drive the location decision-making process in retail businesses. The individual locations, from which the 
businesses can select, vary in price, characteristics of customers who live in or commute to these areas (for work, study, service etc.), in accessibility (central location vs. outskirt), also we can say in visibility, or by connection (supplier-customer) to other units that are already placed in the location, etc. We could probably summarize these characteristics under the term attractiveness. For each retail unit different factors are significant, or rather their particular combination. The requirements will certainly vary depending on the range of goods and services offered. Of course we cannot ignore a number of objectives and relevant (meaning unchangeable) factors in site selection, such as the presence of rivers, significant uneven terrain (hills, rocks) and other geographical characteristics of the territory. As a limiting factor we can also consider the specific functional definition of an area according to the planning requirements of the respective municipality. Due to these and undoubtedly many other factors, the resulting site selection for retail units is always heterogeneous.

The books, Retail Location and Retail Planning (Guy 1980) and Retail Geography (Dawson 1980) were landmark publications in the study of spatial variations in demand and supply of retail activity. Other important and explicitly geographical retail texts followed (Birkin, Clarke, Clarke 2002). In the Czech environment the topic of retail site selection, or shopping centre site selection, and their development has long been the focus of Szczyrba (2005; Kunc et al. 2012). According to Kunc et al. (2012) the construction of shopping centres in the Czech Republic peaked in 20052008. Despite the fact that it is necessary to respect existing spatial structures and regulatory measures (in relation to land use planning), as stated by Viturka et al. (1998), the retail industry is not as sophisticated as production or research, and therefore new stores can be opened relatively quickly throughout the residential system. On the other hand, the aforementioned peak period was followed by a period of decrease in the construction of new centres.

Generally, when selecting a retail business site in a specific area, the following decisive factors need to be considered: structural, demographic, economic, technological, social, and political (Nowosielska 1994 in Toušek et. al. 2008). Their importance in site selection is relative and differentiated with respect to time and space. In relation to retail site selection we also come across the term threshold of goods (Berry et Garrison 1958 cited by Toušek et al. 2008), which is defined as the minimum demand necessary for the existence of a commercial unit.

The proximity, or rather the distance from the retail units' competition, also plays an important role in deciding on the location. Following the development of central place theory in the 1920s, the spatial patterns became a subject for study. The, now classic, Reilly's model - the law of retail gravitation (Reilly 1931) - addresses spatial distribution empirically. The model is based on an analogy with Newton's gravitational model and can be applied to the spatial distribution of retail units. The larger the retail units, the greater their gravitational force that decreases with distance, and in our case from customers. Retail location is founded upon a series of interrelationships, which have strong geographical reference (Guy 1980 in Pacione 1999). Equally important to the law of retail gravitation is Harold Hotelling's (1929) principle of minimum differentiation (for Reilly's and Hotelling's models see more in Findlay, Sparks 2002).

Spatial interaction models and their application to retail site selection are described in Czech geographic literature, namely in the work of Maryáš $(1983,1988)$, who is one of the most important authors. Lee and Pace (2005) refer to the studies by Gautschi (1981) Okoruwa et al. (1988, 1994), as well as Eppli and Shilling (1996), which apply the Reilly gravitational model to specific cases. The results of the conducted studies vary in the importance that they attach to the factors of distance and store size. Lee and Pace (2005) provide an overview of different conclusions that are found in different works. For example, Kotler (1971), Stanley and Sewall (1976) concluded in connection with the size of the store that size does not contribute significantly to the estimated customer size of the store, Okoruwa et al. (1988) assessed the same factor claiming that the size of the shopping 
centre negatively affects the number of customers (i.e. an inverse relationship applies here). Gautschi (1981) followed the importance of the distance between customers and retailers and concluded that this factor tends to be overestimated. Eppli and Shilling (1996) evaluated the distance to the retail units of competitors and empirically documented that this variable is greatly overestimated in the gravity models. The model needs to include other variables. Consequently, Lee and Pace (2005) work with other factors (linked to both the store and the customer), which are the store sales, store size, type and age of the shopping centre (strip, pad, mall), medical supplies expenditure, household income, house value, house age, total population, land area, age, white population, and female population. Distance to the store is measured both in terms of physical distance and in terms of time that a customer spends travelling to the store (from their place of employment).

We suppose that crucial variables are consumers (their characteristics), consumer mobility and income. "Consumers are the lifeblood of the retail industry. It is therefore essential for all retailers to know consumer characteristics." (Birkin, Clarke, Clarke 2002). Consumers' preferences and consumers' habits play an important role. Trouble is that they keep changing - nowadays shopping is about transformation or collecting lifestyle elements or material goods that contribute to the well-being of consumers (Križan, Bilková, Kita 2014).

Individuals are spending more time travelling, both to work and to shop. Guy (1998 cited by Birkin, Clarke, Clarke 2002) notes that increasing mobility has not only allowed consumers greater choice of retail destination, but has also weakened the local monopolies of independent retailers, and allowed more aggressive newcomers to compete on the basis of convenient car access and parking. Better knowledge of the space behaviour of a customer enables the distributer to understand the attractiveness of the sales point and plan the future implantation of a new point of sale (Kita, Grossmanová 2014).

Income is the crucial factor that drives expenditure. Monitoring how much income and expenditure the target group has is an important marketing task (Birkin, Clarke, Clarke 2002).

"Retail gravity models have a limitation that lies in the fact that the resulting catchment areas are distorted as the models consider the centers' influence to be closed and mutually exclusive. But research has confirmed the existence of a transitional area, from which residents, more or less, regularly commute to two or more centres to do their shopping." (Toušek et al. 2008).

In order to select and subsequently evaluate a store site, it is important to analyse the conditions of the examined catchment area. Such analysis contains characteristics of the so called shopping gradient (Zamazalová 2008, p. 134). The shopping gradient is determined by the transfer of purchasing power of the population from their place of residence to another territory. We distinguish between the outer and inner shopping gradient of an area. The outer shopping gradient represents transfers of purchasing power between regions (e.g. shopping in the place of employment, on holiday, etc.) while the inner shopping gradient is reflected within the monitored region.

In defining the area of interest it is possible to use the following methods: circular (uses walking or driving distance), time-space (works with the time that it takes to transfer into the area of interest), econometric (based on gravity), and probability methods.

When assessing an area in terms of total retail capacity we can utilize the spatial standard method. ${ }^{1}$ The capacity is connected with the notion of saturation. The first major spatial examination of saturation came from Myers (1993 cited by Birkin, Clarke, Clarke 2002). Guy (1994a, 1996a in Birkin, Clarke, Clarke 2002) argued that saturation could only be considered in a local context.

\section{Study area and methods}

The retail network was analyzed in the statutory city of Ústí nad Labem, while the retail units exclusively represented trades such as supermarkets and hypermarkets. The analysis relates to 22 areas of the city of Ústí nad Labem 
found in four boroughs. These are - Ústí nad Labem - City, North Terrace, Střekov, and Neštěmice (see Fig. 1). The presented retail site selection analysis was carried out from April to June 2015.

The fundamental criterion for the site selection of retail units was the presence of purchasing power represented by the population living directly within the vicinity of the store, as well as the population living a greater distance away (see Tab. 1).

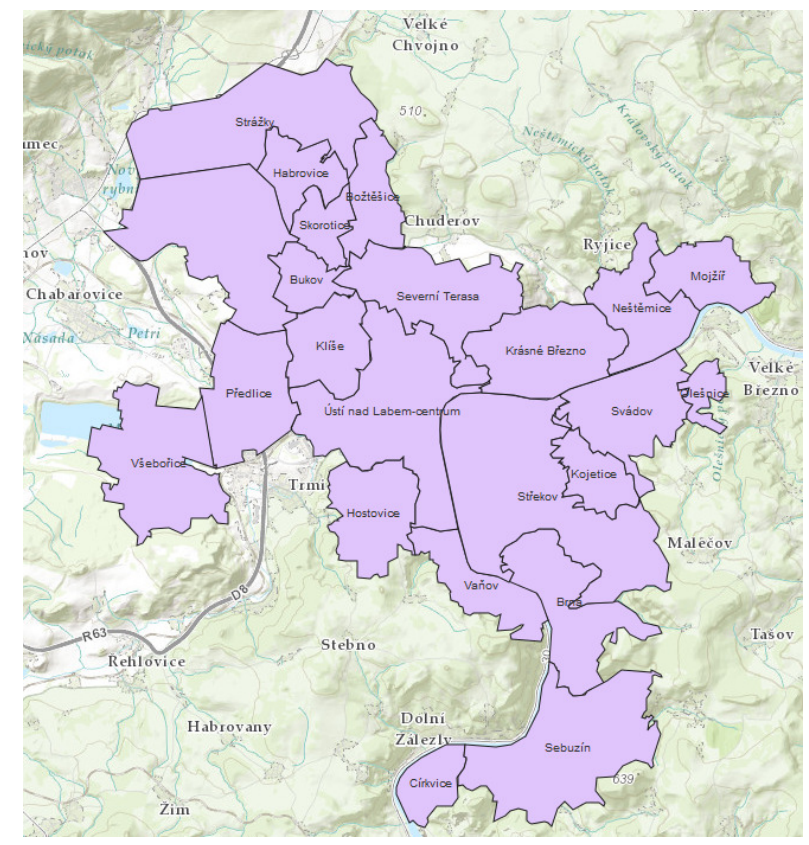

Fig. 1 - Areas of the Ústí nad Labem municipality (Source: processed in ArcGIS, Author's own work)

The fundamental criterion for the site selection of retail units was the presence of purchasing power represented by the population living directly within the vicinity of the store, as well as the population living a greater distance away (see Tab. 1). For the presentation of the selected basic characteristics of the city and its areas the traffic lights method (the values that represent the city of Ústí nad Labem as a whole were determined as the mean between minimum and maximum) and data stripes were used. The largest area of the city in terms of number of inhabitants is North Terrace $(20,500 \mathrm{inh}$.), followed by Ústí nad Labem - Center (13,935 inh.) and Krásné Březno $(13,294$ inh.). At the other end of the spectrum, based on the number of inhabitants, are mostly areas belonging to the Střekov district (Olešnice with 89 inh., Kojetice with 133 inh. and Církvice with 185 inh.). The proportional representation of the 15-64 age group in the individual areas of the city was monitored, while better evaluation was received by city areas where the representation of this age group was higher (compared with the representation of the city as a whole). The most favourable age structure of customers was in the Mojžiřr, Olešnice, and Všebořice areas. To the contrary, the proportional representation of the 65 years and more age group was evaluated negatively because of the lower probability of a significant proportion of economically active population and population with higher disposable income in this group. Therefore, the least favourable situation in this respect was in the Bukov, Ústí nad Labem - Center and Brná areas. The highest proportion of economically active residents (positive characteristic) was in the Olešnice, Všebořice, and Vaňov areas.

In terms of placing a supermarket/hypermarket in a particular area it would be rather inconvenient if the economically active residents commuted from this area to work. It can then be expected that they will realize most purchases at their workplace and not at their place of residence. In this regard it appears that the relatively least suitable locations are in the Církvice, Vaňov, and Strážky areas.

\subsection{Location of supermarkets}

In the city of Ústí nad Labem, retail units of the supermarket or hypermarket type are unevenly distributed and are concentrated in the more central areas of the city. Out of the 22 areas only six contain these types of stores (see Fig. 2).

\subsection{The impact of city areas characteristics on the selection of a store location}

Although this article is based on a grant project that included field research and interviews with standardized questionnaire sheet, it failed to obtain the data to evaluate the effect of location factors (see Section 2).

For interviews were asked representatives of all business units monitored. The absolute majority of them refused to provide any information. It is 
therefore impossible to verify the reasons for locating the unit in a particular place or economic success of the unit.

From secondary sources, specifically from the cadastre of real estates were acquired at least information about the physical size of the units, respectively buildings in which the premises are located (the size of the premise and size of the building are not always identical). Further interviews were focused on customers.

Table 1 - Selected characteristics of the city of Ústí nad Labem and its areas

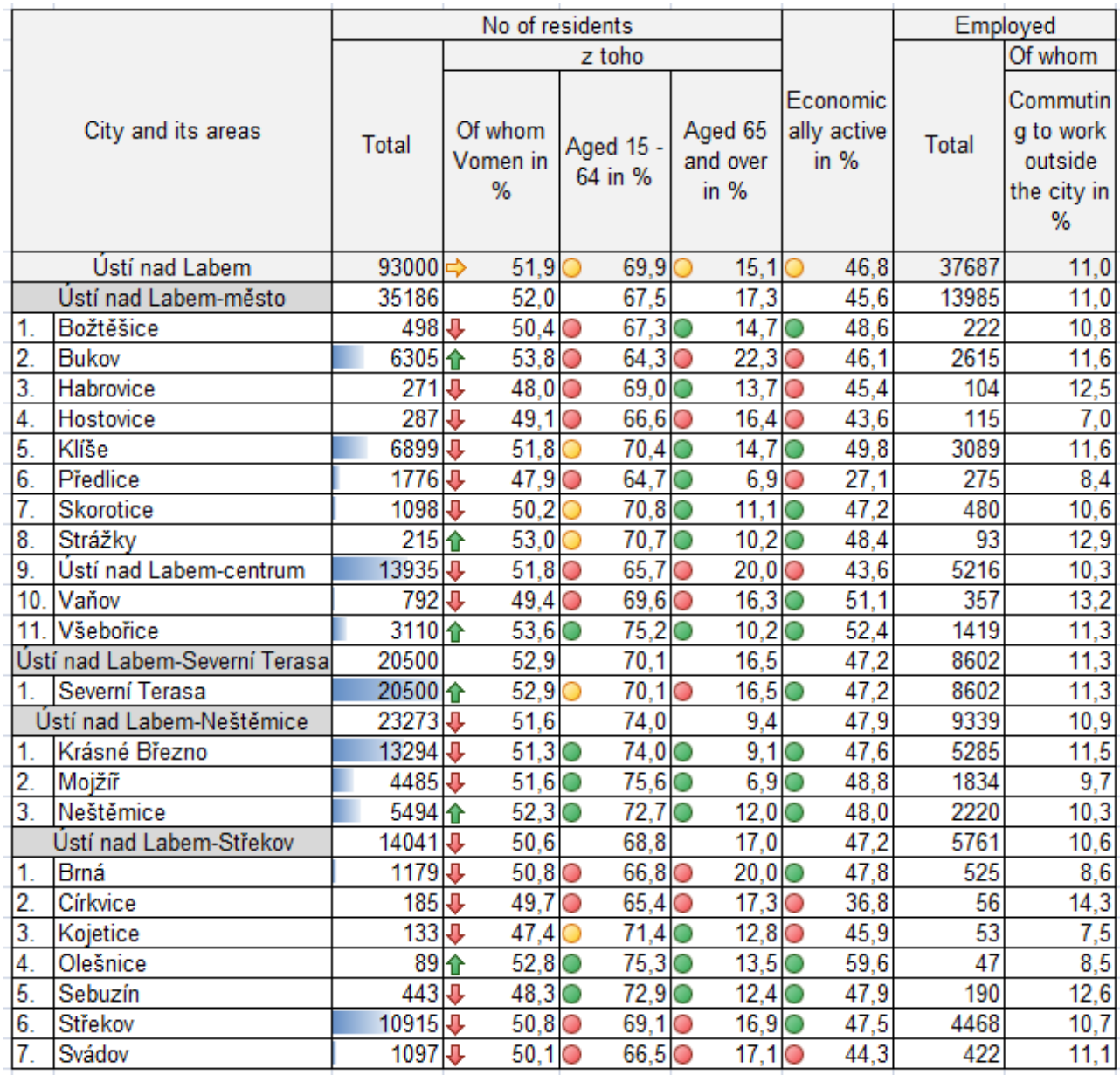

Source: author's own work based on Statistický lexikon obcí 2013 data (Statistical Lexicon of Municipalities)

In some instances, the customer interviewing was forbidden by authorities of the retail unit and interviewers were banned from the site. Consequently, it was not possible to achieve a representative sample of respondents. Some data about customers and their shopping behaviour, e.g. household income, frequency of purchases, the distance between the residence and trade, can not be obtained for the level of the city from secondary data sources, it is not surveyed.

Due to the unavailability of data that characterize possible site selection factors we used selected characteristics of different areas of the city containing the monitored retail units in order to analyze their impact. This includes the following characteristics: the size of the area measured by the number of inhabitants, the proportion of women in the population of the area, the proportion of the 15-64 age group in the population of the area, the proportion of economically active population in the total population, the proportion of the population commuting to work out of the total number of those employed in the community. Using correlation analysis, we verified the existence and strength of the 
relationship between individual characteristics and the number of monitored ${ }^{2}$ retail units in the relevant areas of the city. Except for the commuting population indicator, we would expect that the number of stores would positively correlate with the rest of the indicators. But this assumption was not confirmed. The correlation coefficient value for the relationship between number of stores and population is 0.52 . The coefficient value is not high enough in order to reach a strong conclusion. The coefficient for the relationship between the number of stores and the proportion of women (here we assume the leading role of women in making purchasing decisions and their implementation) has a value of 0.17 , which means that there is probably no relationship between variables or the relationship is not linear. The coefficient for the relationship between the number of stores and the proportion of the 15-64 age group has a value of - 0.67 , which indicates the existence of a negative linear relationship. For the relationship between the number of stores and the proportion of economically active the value is -0.67 , again indicating a negative linear relationship. The last is the correlation coefficient value for the relationship between the number of stores and the proportion of those who commute out of the city to work, which is -0.28 . The value indicates a negative relationship, but it is too low to provide a definite conclusion. It would certainly be appropriate to include other variables in the analysis disposable household income, household structure, etc. However, for these there are no data available.

\subsection{Areal standard distribution}

For the calculation and assessment of the areal standard we used the size of the land on which the buildings of the monitored store units stood, instead of the size of the sales area. It was not possible to obtain the sales area indicator as in the course of the investigation the addressed stores refused to provide this information.

However, the land area is in some cases very misleading, e.g. where supermarkets or hypermarkets are part of a larger shopping centre (esp. Tesco and Billa in Ústí nad Labem - Centre).

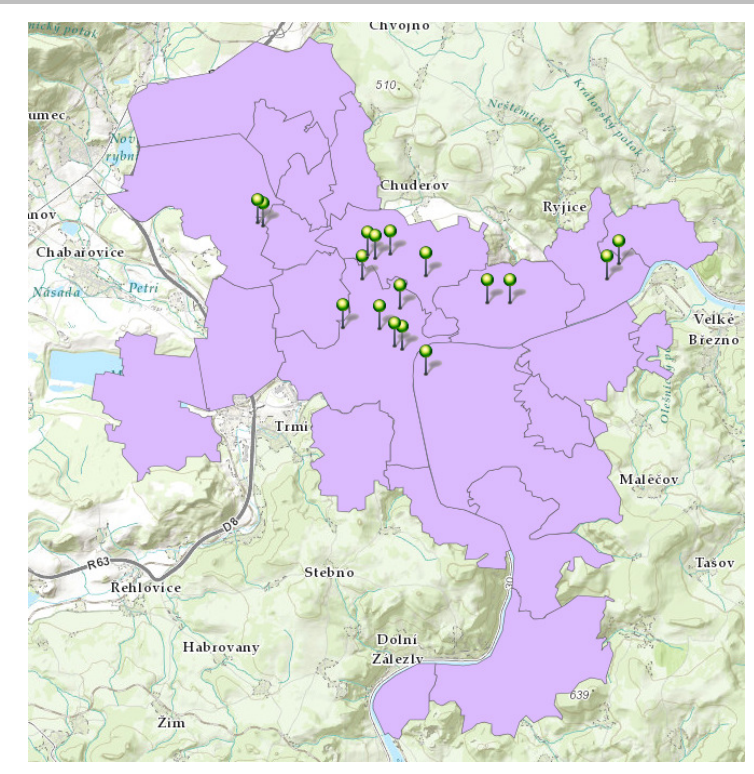

Fig. 2 - Location of supermarkets (Source: processed in ArcGIS, Author's own work)

The value of the areal standard for the whole city is about $0.64 \mathrm{~m}^{2} / \mathrm{inh}$. The highest value was displayed by Ústí nad Labem - Center with $2.38 \mathrm{~m}^{2} /$ inh., which was followed by Všebořice with $2.16 \mathrm{~m}^{2} / \mathrm{inh}$. On the other side of the scale there are Střekov $\left(0.13 \mathrm{~m}^{2} /\right.$ inh.) and Krasné Brezno $\left(0.24 \mathrm{~m}^{2} / \mathrm{inh}\right.$.). The value of the areal standard for Ústí nad Labem - Centre is significantly distorted, or rather overestimated, by the fact that the supermarkets (Tesco, Billa) in this location represent a part of larger shopping units. Therefore, realistically, the first position belongs to Všeborice, even though this city area is not one of the most populated nor one with the highest population density. North Terrace $\left(0.62 \mathrm{~m}^{2} /\right.$ inh. $)$ dis-played the second highest areal standard (excluding Ústí nad Labem - Centre). North Terrace is the largest area of the city in terms of population and the second largest in terms of population density.

\section{Results}

\subsection{Catchment area - walking distance (10 min.)}

The catchment area of each store is also determined by walking distance, from which it is possible to reach the store. A distance corresponding to ten-minute walk was chosen to define the location. Due to the frequent spatial concentration of shops within walking distance a number of shops 
overlap. They nearly overlap in the case of Lidl and Kaufland in Všebořice as the stores are located next to each other. On the contrary Penny Market in Střekov does not have any competition in terms of catchment area, as the River Elbe creates a significant barrier and limits visits to the store. Lidl on the North Terrace also has a relatively exclusive position in the area.

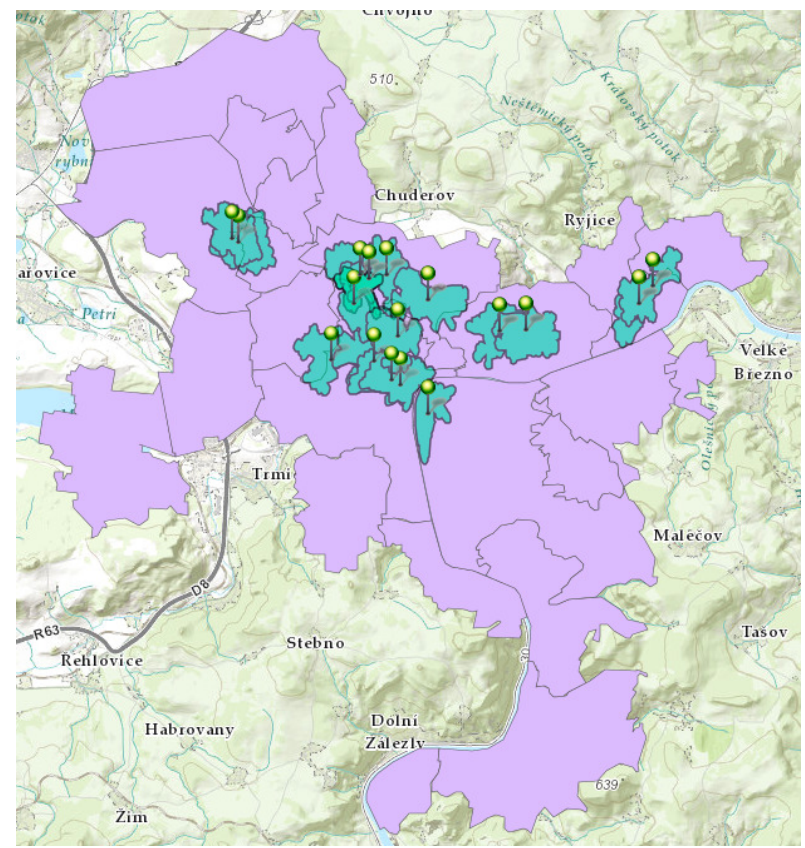

Fig. 3 - Catchment area of the stores (walking distance 10 min., processed in ArcGIS, Author's own work)

\subsection{Catchment area - commuting distance (15 min.)}

Apart from walking distance we also used commuting distance to determine the catchment area. It was again measured in time, namely 15 minutes. It is possible to access at least one supermarket or hypermarket from anywhere in the city within this time. Relatively large distances beyond the borders of the city can be reached, especially along main routes. Therefore, the catchment area is of a radial shape (Fig. 4). But we can not expect that from all identified commuting distances customers would actually travel to one of the Ústí stores. We must also take into account the competition in the surrounding towns. It can be assumed that the maximum distance, from which customers commute to shops, corresponds to the identified catchment area of Ústí nad Labem (see Fig. 5).

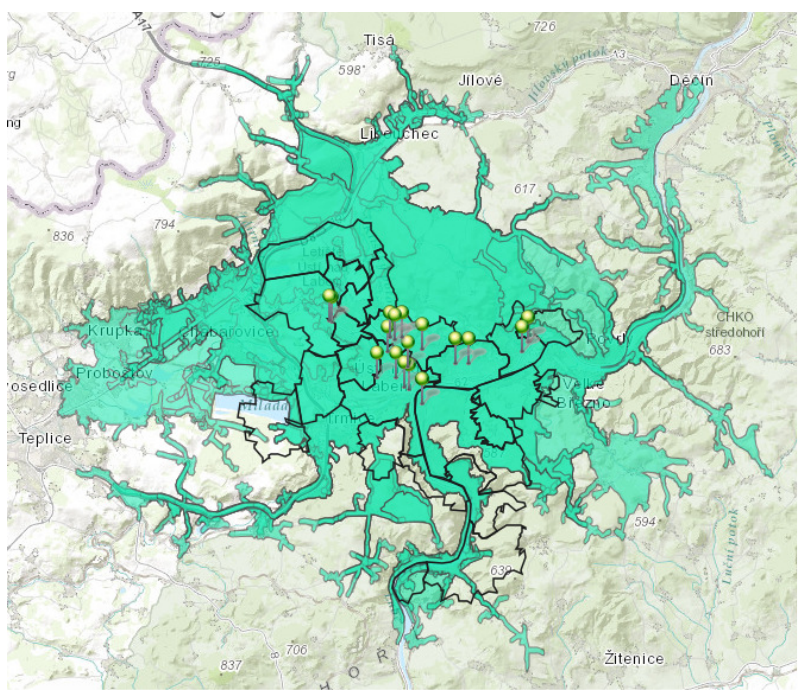

Fig. 4 - Catchment area of the stores (commuting distance 10 min., processed in ArcGIS, Author's own work)

Table 2 - Supermarkets and hypermarkets in Ústí nad Labem (author's own work, www.cuzk.cz)

\begin{tabular}{llr} 
store name & location - city area & \multicolumn{1}{c}{$\begin{array}{l}\text { area } \\
\left(\mathrm{m}^{2}\right)\end{array}$} \\
\hline LIDL & Všebořice & 1851 \\
Tesco & Ústí n. L. - centrum & 5313 \\
BILLA & Ústí n. L. - centrum & 16341 \\
Kaufland & Ústí n. L. - centrum & 6959 \\
Kaufland & Všebořice & 4865 \\
Penny Market & Ústí n. L. - centrum & 2530 \\
NORMA & Ústí n. L. - centrum & 1191 \\
JIP & Ústí n. L. - centrum & 826 \\
LIDL & Severní terasa & 1930 \\
Albert & Severní terasa & 7881 \\
BILLA & Severní terasa & 939 \\
NORMA & Severní terasa & 1859 \\
Penny Market & Střekov & 1427 \\
Tesco & Neštěmice & 1317 \\
Albert & Neštěmice & 965 \\
BILLA & Krásné Březno & 1921 \\
Penny Market & Krásné Březno & 1251
\end{tabular}

Territory in fig. 5 was defined by applying Reilly gravity model, respectively. breaking points were calculated; from the north the territory is defined 
by national boundaries. As competitive centers for Usti nad Labem were considered these cities: Děčín, Teplice and Litoměřice.

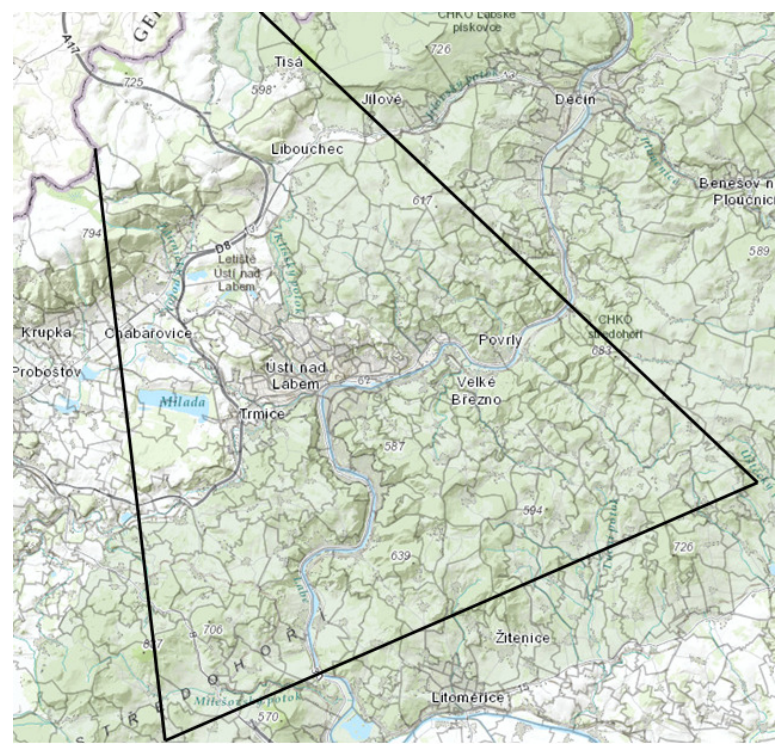

Fig. 5 - Catchment area of Ústí nad Labem (Reilly model - breaking point, processed in ArcGIS, Author's own work)

\section{Conclusion}

The market analysis of a retail store is an important stage of the process during which a distributor decides on investing in the creation of a new point of sale in the surveyed area. Part of the decision-making process of the distributor is also the selection of a suitable site for the new store.

The retail units, of supermarket and hypermarket types, in Ústí nad Labem are located rather in the central parts of the city. Their location does not display a significant correlation with customer potential, represented mainly by the number of inhabitants in the respective area. Due to the frequent spatial proximity of the stores their catchment area, as defined by walking distance, often overlap. In terms of commuting distances, the stores are accessible from surrounding towns, but due to the competition from these towns to the whole of Ústí nad Labem we can not expect significant commuting from these towns. None of the investigated site selection factors were confirmed to have a definite effect. The future effort should be aimed at verification of other possible site selection factors, which, however, drives at unavailability of data. Therefore, setting up the database about retailing should be the next step.

\section{Notes}

${ }^{1}$ Other methods used are turnover, retail saturation index, regression analysis, and analogy methods.

${ }^{2}$ It probably would have been more appropriate to replace the number of stores by the size of the sales area. The values of this indicator could not have been obtained; therefore, in this paper the size of the sales area is replaced with the size of the land on which the building, which contains the store, stands. However, in many cases this data is significantly distorted.

\section{Acknowledgements}

The article was developed by the student grant project of UJEP Ústí nad Labem "Using geomarketing in the analysis of purchasing power in the region."

\section{References}

Birkin M, Clarke G, Clarke MP (2002) Retail Geography and Intelligent Network Planning. Wiley.

Dawson JA (2013 ed.) Retail Geography. Routledge, London and New York.

Dawson JA (1980) Retail Geography. Croom Helm, London.

Eppli MJ, Shilling JD (1996) How Critical is a Good Location to a Regional Shopping Center? Journal of Real Estate Research 12: 459-468.

Findlay AM, Sparks L (2002 eds.) Retailing. Critical Concepts. Vol. I. The Evolution and Development of Retailing. Routledge, London and New York.

Gautshi DA (1981) Specification of Patronage Models for Retail Center Choice. Journal of Marketing Research 18: 162-174.

Guy CM (1980) Retail Location and Retail Planning in Britain. Gower.

Kita P, Grossmanová M (2014) Reflection of Bratislava Retail Network in Selected Aspects of Consumer Behaviour. Verslas: Teorija ir Praktika/Business: Theory and Practice 15(3): 279-284.

Kotler P (1971) Marketing Decision Making: A Model Building Approach. New York: Holt, Rinehart and Winston.

Križan F, Bilková K, Kita P (2014) Urban retail market in Bratislava (Slovakia): Consumers perception and classification of shopping centres. Management \& Marketing. Challenges for the Knowledge Society 9(4): 483-500.

Kunc J, Tonev P, Frantál B, Szczyrba Z (2012) Shopping gradient, shopping behaviour and shopping centres: the example of Brno agglomeration (contribution to 
the study of daily urban systems). In: Sociological Review, vol. 48, no. 5, 2012.

Kunc J, Tonev P, Greplová Z, Szczyrba Z (2012) Prospects of Czech shopping centres in view of their urban localization: the example of the city of Brno. In: Urbanism and Territorial Development, no. 2/2012.

Lee M-L, Pace RK (2005) Spatial Distribution of Retail Sales. The Journal of Real Estate Finance and Economics 31(1): 53-69.

Maryáš J (1983) K metodám výběru středisek maloobchodu a sfér jejich vlivu. Zprávy Geografického ústavu ČSAV, 20, 3, Geografický ústav ČSAV, Brno.

Maryáš J (1988) Nadmístní střediska maloobchodu a služeb v ČSSR a jejich sféry vlivu. Geografický ústav ČSAV, Brno.

Okoruwa AA, Nourse HO, Terza JV (1994) Estimating Sales for Retail Centers: An Application of the Poisson Gravity Model. Journal of Real Estate Research 9: 8597.

Okoruwa AA, Terza JV, Nourse HO (1988) Estimating Patronization Shares for Urban Retail Centers: An
Extension of the Poisson Gravity Model. Journal of Urban Economics 24: 241-259.

Pacione M (1999 ed.) Applied geography: principles and practice. An introduction to useful research in physical, environmental and human geography. Routledge, London and New York.

Stanley TJ, Sewall MA (1976) Image Inputs to a Probabilistic Model: Predicting Retail Potential. Journal of Marketing 40: 48-53.

Szczyrba Z (2005) Retail industry in the Czech Republic after 1989: The development and trends with a focus on geographical organization. Palacky University, Olomouc.

Toušek V, Kunc J, Vystoupil J et al. (2008) Ekonomická a sociální geografie. Aleš Čeněk, Plzeň.

Viturka M, Maryáš J, Toušek V, Vystoupil J (1998) Investiční atraktivita vybraných měst České republiky. Masarykova univerzita, Brno.

Zamazalová M (2008) Marketing obchodní firmy. Grada, Praha. 